\title{
Correction to: Growth models and growing degree-days: assessment of young-of-year alewife and blueback herring in Potomac River tributaries
}

\author{
Samantha B. Alexander (D) - CJ Carroll Schlick (D) • \\ Kim de Mutsert (iD
}

Published online: 1 September 2020

(C) Springer Nature B.V. 2020

\section{Correction to: Environmental Biology of Fishes. https://doi.org/10.1007/s10641-020-01012-4}

Due to an oversight during typesetting, the original version of this article unfortunately contained a mistake. The second author's name is CJ Carroll Schlick, not Carroll Schlick.

The original article has been corrected.

Publisher's note Springer Nature remains neutral with regard to jurisdictional claims in published maps and institutional affiliations.

The online version of the original article can be found at https://doi.org/10.1007/s10641-020-01012-4

S. B. Alexander $(\square) \cdot$ C. C. Schlick $\cdot$ K. de Mutsert Department of Environmental Science and Policy, George Mason University, 4400 University Drive, Fairfax, VA 22030, USA

e-mail: salexa14@masonlive.gmu.edu

C. C. Schlick

North Carolina Division of Marine Fisheries, Morehead City, NC 28557, USA 